Kelola

Jurnal Manajemen Pendidikan

Magister Manajemen Pendidikan

ISSN 2443-0544

FKIP Universitas Kristen Satya Wacana

jurnalkelola@gmail.com

Volume: 3, No. 2, Juli-Desember 2016

Halaman: 246-264

\title{
EVALUASI PROGRAM SISTEM KREDIT SEMESTER DI SMA NEGERI 1 SALATIGA
}

\author{
Agustina Tyas Asri Hardini \\ Program Studi S1 Pendidikan Guru Sekolah Dasar \\ FKIP-Universitas Kristen Satya Wacana \\ tyasasri89@gmail.com \\ Bambang Suteng Sulasmono \\ Program Pascasarjana Magister Manajemen Pendidikan \\ FKIP-Universitas Kristen Satya Wacana \\ bambang.sulasmono@staff.uksw.edu
}

\begin{abstract}
This study aimed to evaluate semester credit system program in SMA Negeri 1 Salatiga. This study was as evaluation research by using CIPP models (Context, Input, Process, and Product) along with qualitative descriptive approach. This data collected by interviews, documentations and observation. The data were analyzed by applying Miles and Huberman theory in Sugiyono (2013:95) that consisted of data collection; data reduction; data display; and conclusions. This study use triangulation technique to test the validity of data. The result showed that: 1) SMAN 1 Salatiga Semester Credit System Program implementation in context evaluation based on the needs of learners possess special smart categories; 2) SMAN 1 Salatiga Semester Credit System Program implementation in input evauation include the plan, mechanism implementation, teachers, learners, finance, infrastructure, and schedule are valued as sufficient; 3) SMAN 1 Salatiga Semester Credit System Program implementation in process evaluation have been carried out as planned program although there are still some obstacles, but have been already handled well; 4) SMAN 1 Salatiga Semester Credit System Program implementation in terms of the results were in accordance with the original purpose of the program, that was to facilitate learners with smart category Outstanding in order to complete their high school studies only for 2 years.
\end{abstract}

Keywords: Evaluation Program, Semester Credit System, CIPP

\section{PENDAHULUAN}

UU No 20 Tahun 2003 bab II pasal 3 yang menetapkan bahwa: "Pendidikan nasional berfungsi mengembangkan kemampuan dan membentuk watak serta peradaban bangsa yang bermartabat dalam rangka mencerdaskan kehidupan bangsa".Dalam rangka mencapai tujuan pendidikan yang diharapkan tersebut, diperlukan pembelajaran yang berkualitas dan efektif. 
Dimana menurut pendapat Bloom (1976:34) terdapat hal-hal yang perlu diperhatikan dalam pembelajaran yakni individual differences in learning that is an observable phenomenon which can be predicted, explained, and altered in a great variety of ways.

Pendapat tersebut tampaknya diadopsi oleh Aunurrahman (2009:33) yang menyatakan bahwa setiap orang berbeda satu antara satu dengan yang lain dan tidak satupun yang memiliki ciri-ciri yang sama.Setiap individu pasti memiliki karakteristik yang berbeda dengan individu yang lainnya.Perbedaan individual ini merupakan kodrat manusia yang bersifat alami. Perbedaan individu tersebut disebabkan oleh besarnya variasi dalam kemampuan seperti yang dikatakan oleh Hirsch (1999:12) bahwa variations in ability and learning style are caused by individual differences. Oleh karena itu, Hirsch (1999:12) menyatakan bahwa individual differences are mainly differences in academic preparation and ability, and the accommodation of these differences take the form of ability tracking.

Berdasarkan pendapat para ahli tersebut para pengambil kebijakan di Indonesia telah mengupayakan supaya pengembangan kemampuan peserta didik dapat disesuaikan dengan kebutuhannya.Seperti yang tercantum dalam Undang-undang Nomor 20 Tahun 2003 tentang Sistem Pendidikan Nasional Pasal 12 ayat (1) yang menyatakan bahwa:"Setiap peserta didik pada setiap satuan pendidikan berhak mendapatkan pelayanan pendidikan sesuai dengan bakat, minat dan kemampuannya".Selanjutnya pada butir (f) dinyatakan "Peserta didik pada setiap satuan pendidikan berhak menyelesaikan pendidikan sesuai dengan kecepatan belajar masing-masing dan tidak menyimpang dari ketentuan batas waktu yang ditetapkan”.

Pemerintah kemudian merintis SMA/MA/ SMLB, SMK/MAK dengan Sistem Kredit Semester (SKS). Adapun dasar lain dari program SKS adalah Peraturan Pemerintah Nomor 19 tahun 2005 tentang Standar Nasional Pendidikan pasal 11 ayat (2) juga menyebutkan bahwa "Beban belajar untuk SMA/MA/SMLB, SMK/MAK atau bentuk lain yang sederajat pada jalur pendidikan formal kategori standar dapat dinyatakan dalam satuan kredit semester." selanjutnya pada ayat (3) menyebutkan "Beban belajar untuk SMA/MA/SMLB, SMK/MAK atau bentuk lain yang sederajat pada jalur pendidikan formal kategori mandiri dapat dinyatakan dalam satuan kredit semester." Berdasarkan alasan-alasan tersebut kemudian pemerintah mengeluarkan Peraturan Menteri Pendidikan dan Kebudayaan (Permendikbud) nomor 158 Tahun 2014 yang mengatur tentang penyelenggaraan Sistem Kredit Semester pada pendidikan dasar dan pendidikan menengah, dimana di dalam Peraturan Menteri Pendidikan dan Kebudayaan tersebut pemerintah menjabarkan tentang syarat-syarat sekolah yang ingin menyelenggarakan SKS dan tata cara penyelenggaraannya. 
Berdasarkan hasil penelitian pendahuluan, Sekolah Menengah Atas Negeri (SMAN) 1 Salatiga merupakan salah satu sekolah menengah yang telah menerapkan program Sistem Kredit Semester (SKS) sejak tahun pelajaran 2012/2013.SMAN 1 Salatiga merupakan satusatunya sekolah menengah di Salatiga yang telah menerapkan sistem kredit semester (SKS).Berdasarkan fakta tersebut peneliti simpulkan bahwa program SKS ini merupakan sesuatu yang baru dalam dunia pendidikan di jenjang Sekolah Menengah Atas, sehingga pengimplementasiannya menimbulkan banyak pertanyaan.

Berdasarkan wawancara pendahuluan yang dilakukan di SMAN 1 Salatiga, dengan narasumber wakil kepala sekolah bagian kurikulum Bapak Budiyanto,tampak bahwa sistem kredit semester ini menuntut peserta didik untuk mandiri serta bertanggungjawab terhadap rencana program studinya.Sebagai contoh jika semakin baik nilai indeks prestasi kumulatif (IPK), maka semakin banyak pula mata pelajaran yang dapat diikuti di semester berikutnya.Demikan juga ketika ada peserta didik yang nilainya tidak memenuhi standar KKM (Kriteria Ketuntasan Minimal) maka harus mengikuti kegiatan remidi.Jika remidi masih belum memenuhi standar KKM, maka harus mengikuti perbaikan di semester pendek, dengan tujuan untuk memperbaiki nilai yang telah diperoleh pada semester sebelumnya.

Tujuan diadakannya evaluasi program di SMA Negeri 1 Salatiga adalah mengetahui ketercapaian tujuan dari program dengan langkah mengetahui keterlaksanaan kegiatan program, karena peneliti ingin mengetahui bagian mana dari komponen dan subkomponen program yang belum terlaksana dan apa sebabnya (Arikunto dan Jabar, 2010:18).Lebih dari itu berdasarkan beberapa kendala yang peneliti temukan, maka peneliti bermaksud untuk mengevaluasi penerapan sistem kredit semester di SMA Negeri 1 Salatiga, dan melihat sudahkah program SKS yang dilaksanakan sesuai dengan panduan yang dikeluarkan oleh Badan Sandar Nasional Pendidikan (BSNP).Peneliti akan melakukan evaluasi menggunakan model CIPP (Context, Input, Process, Product).Model CIPP dipilih karena model ini memandang program yang dievaluasi sebagai sebuah sistem (Arikunto dan Jabar, 2010:45).

Berbagai definisi evaluasi program yang dipaparkan oleh Ralp Tyler dalam Arikunto (2010:5), Arikunto \& Jabar (2010:2), Stufflebeam (2008:20) dan Mugiadi (2008:21), dan Wirawan (2012:17), memiliki beberapa persamaan, diantaranya adalah tentang terdapatnya serangkaian kegiatan sistematis yang harus dilakukan dalam menerapkan evaluasi program, selain itu terdapat data yang harus digunakan dalam evaluasi program. Namun cara pengolahan data yang dipakai oleh beberapa ahli tersebut berbeda-beda, selain itu kegunaan dari evaluasi program tersebut juga berbeda, Ralp Tyler menyebutkan kegunaan evaluasi program sebagai penjabaran apakah tujuan pendidikan sudah tercapai, sedangkan Stufflebeam 
menyebutkan kegunaan evaluasi program sebagai informasi untuk menetapkan alternatif keputusan, dimana hal ini sejalan dengan pendapat Mugiadi.Melalui beberapa pendapat diatas maka dapat peneliti simpulkan bahwa evaluasi program merupakan serangkaian kegiatan sistematis yang dilakukan untuk mengumpulkan informasi tentang suatu program, guna mengambil alternatif kebijakan yang akan berpengaruh terhadap keberlanjutan program.

Dari pendapat beberapa pakar meliputi: Wirawan (2012:17), Taylor (2010:12), dan Mulyatiningsih (2011:11), secara keseluruhan peneliti simpulkan bahwa evaluasi program bertujuan untuk mengetahui pencapaian keberhasilan suatu program dan manfaat dari program yang dievaluasi terhadap keberlanjutan tujuan organisasi,dimana nanti hasil dari evaluasi dapat digunakan sebagai rekomendasi pengambilan keputusan bagi keberlanjutan program, apakah dihentikan, dilanjutkan atau diperbaiki.

Wirawan (2012:92) menyatakan bahwa model CIPP terdiri dari empat jenis evaluasi, yaitu evaluasi konteks (context evaluation), evaluasi masukan (input evaluation), evaluasi proses (process evaluation), dan evaluasi produk (product evaluation), yang dilukiskan pada gambar berikut:
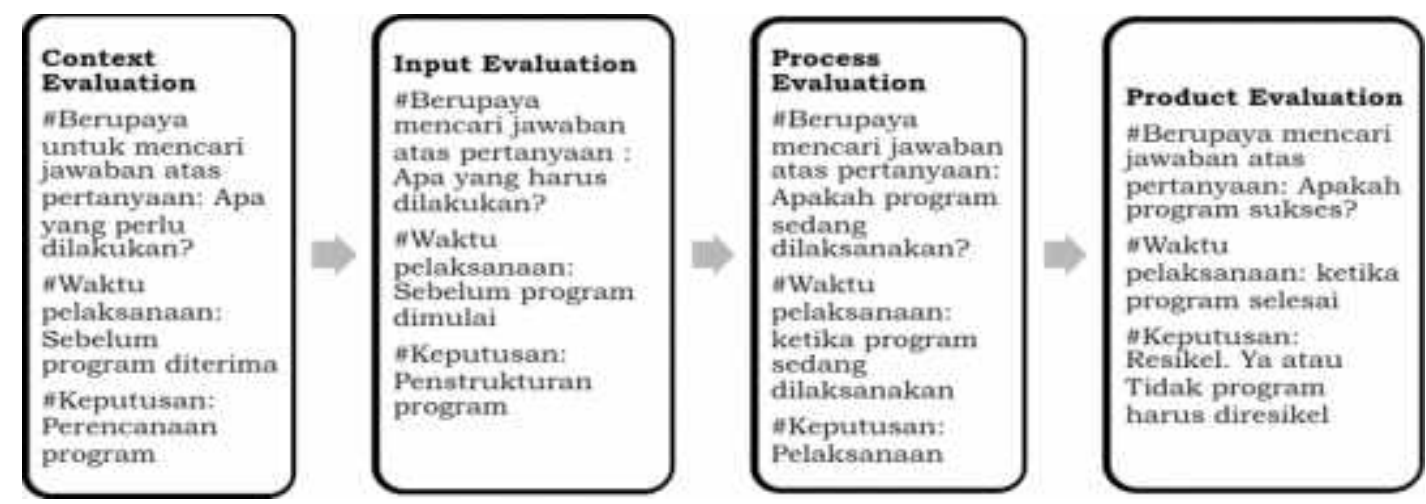

\section{Gambar 1. Model Evaluasi Context, Input, Process, Product}

Sumber: Wirawan, 2012:92

Stufflebeam yang dikutip oleh Wirawan (2012:94) mengembangkan 10 checklist sebagai panduan bagi peneliti dalam melaksanakan model evaluasi CIPP.Fungsi dari checklist untuk membantu peneliti mengevaluasi program yang secara relatif mempunyai tujuan jangka panjang.Dari kesepuluh checklist yang Wirawan (2012:94-100) paparkan, peneliti hanya akan menggunakan 4 checklist saja yang sesuai dengan penelitian yang akan peneliti lakukan, meliputi evaluasi konteks, evaluasi masukan, evaluasi proses, dan evaluasi keberlanjutan sebagai evaluasi hasil. 
Nugroho (2008:559) yang menyebutkan bahwa setiap evaluasi kebijakan menghasilkan kesimpulan,apakah kebijakan dihentikan,ataukah dilanjutkan.Jika dilanjutkan, apakah tetap, ataukah direvisi. Proses pasca-evaluasinya dapat digambarkan sebagai berikut:

\section{Gambar 2. Pasca-Evaluasi}

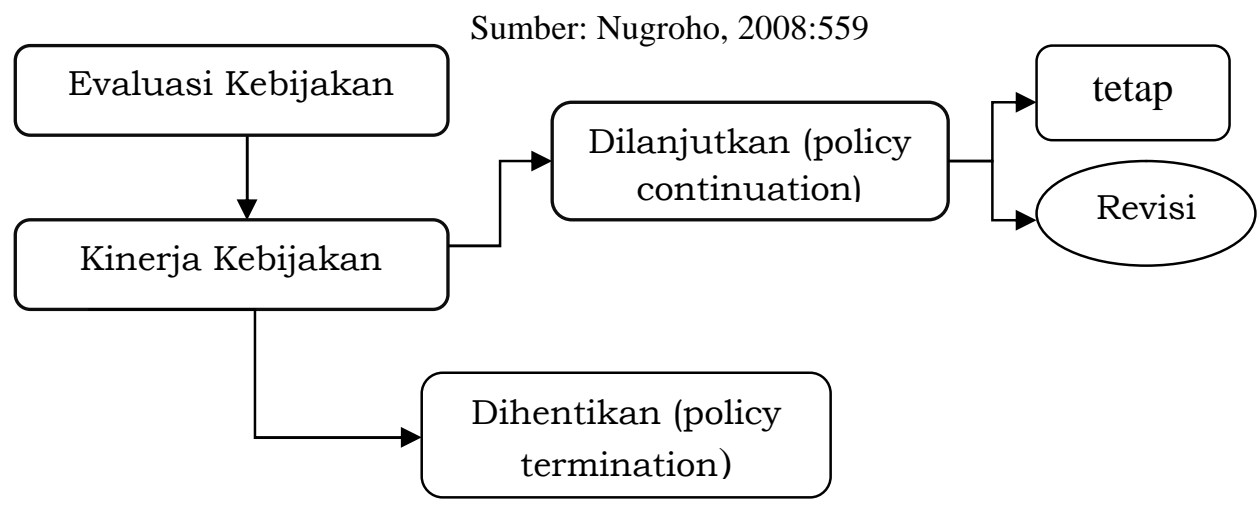

Program sistem kredit semester pada jenjang pendidikan menengah merupakan suatu upaya inovatif untuk meningkatkan mutu pendidikan.Pada hakikatnya, SKS merupakan perwujudan dari amanat Undang-Undang Nomor 20 tahun 2003 tentang Sistem Pendidikan Nasional pasal 12 ayat (1).Amanat dari pasal tersebut selanjutnya dijabarkan lebih lanjut dalam Peraturan Pemerintah Nomor 19 Tahun 2005 tentang Standar Nasional Pendidikan dan Peraturan Menteri Pendidikan Nasional Nomor 22 Tahun 2006 tentang Standar Isi.

Standar Isi mengatur bahwa beban belajar terdiri atas dua macam, yaitu: (1) Sistem Paket, dan (2) Sistem Kredit Semester. Berdasarkan Badan Standar Nasional Pendidikan (BSNP) tahun 2010 tentang Panduan Penyelenggaraan Sistem Kredit Semester, latar belakang munculnya sistem kredit semester ini dikarenakan kelemahan sistem paket yang hanya memberikan satu kemungkinan, yaitu seluruh peserta didik wajib menggunakan cara yang sama untuk menyelesaikan program belajarnya. Implikasi dari hal tersebut yaitu peserta didik yang pandai akan dipaksa mengikuti peserta didik lainnya yang memiliki kemampuan dan kecepatan belajar standar. Berbeda dengan sistem paket, sistem kredit semester (SKS) memberi kemungkinan untuk menggunakan cara yang lebih variatif dan fleksibel sesuai kemampuan, bakat, dan minat peserta didik.Oleh karena itu penerapan SKS diharapkan bisa mengakomodasi kemajemukan potensi peserta didik. Melalui SKS, peserta didik juga dimungkinkan untuk menyelesaikan program pendidikannya lebih cepat dari periode belajar yang ditentukan dalam setiap satuan pendidikan. Sistem kredit semester ini kemudian 
diperjelas dengan munculnya Peraturan Menteri Pendidikan dan Kebudayaan Nomor 158 tahun 2014 tentang Penyelenggaraan Sistem Kredit Semester pada Pendidikan Dasar dan Pendidikan Menengah.Penyelenggaraan sistem kredit semester di sekolah menengah mengacu pada Badan Standar Nasional Pendidikan (BSNP, 2010).

Adapun kajian atau hasil penelitian terdahulu berkaitan dengan penelitian ini, meliputi penelitian pertama yang dilakukan Nurmalisa (2013) yang berjudul Pengaruh Kesiapan Sekolah terhadap Pelaksanaan Program Sistem Kredit Semester di SMA Negeri 9 Bandar Lampung Tahun Pelajaran 2012/2013 menemukan bahwa terdapat pengaruh kuat antara kesiapan sekolah terhadap pelaksanaan sistem kredit semester di SMA Negeri 9 Bandar Lampung.Kesiapan sekolah ini meliputi kesiapan guru, siswa, sarana prasarana serta lingkungan terhadap program sistem kredit semester.

Penelitian kedua, oleh Sa'diyah (2012) dengan judul Implementasi Kurikulum Tingkat Satuan Pendidikan pada Mata Pelajaran Sejarah dengan Sistem Kredit Semester di SMA Negeri 2 Malang Tahun Ajaran 2011/2012 menyebutkan bahwa secara keseluruhan pemahaman guru sejarah di SMA Negeri 2 Malang mengenai KTSP dan SKS tidak hanya mengetahui garis besarnya, namun juga memahami konsep dasar KTSP, akan tetapi untuk penerapan SKS di SMA Negeri 2 Malang masih mengalami hambatan.

Penelitian ketiga,oleh Rakhmawati (2011) tentang Implementasi Program Sistem Kredit Semester (SKS) dalam Upaya Peningkatan Mutu Pendidikan di Sekolah Menengah Atas Negeri 3 Bandung menyimpulkan bahwa implementasi program SKS di SMAN 3 Bandung sudah cukup sesuai dengan panduan penyelenggaraan program yang diterbitkan oleh BSNP.Dampak dari implementasi program SKS ini adalah meningkatnya kualitas layanan pembelajaran terutama pada bidang sarana prasarana sekolah serta aspek komunikasi dan interaksi sekolah dengan orangtua siswa.

Penelitian keempat, oleh Feldhaus dan Omori (2010) dalam jurnal yang berjudul "Who does a beter job?Work quality and quantity comparison between student volunteers and students who get extra credit" menemukan bahwa di antara mahasiswa yang melakukan kegiatan kemahasiswaan di kampus,mahasiswa yang mengambil SKS lebih banyak dibandingkan teman-temannya, dan mahasiswa yang melakukan pelayanan kemanusiaan ternyata ketika dilakukan penelitian,mahasiswa yang mengambil SKS lebih banyaklah yang nilainya paling bagus diantara mahasiswa-mahasiswa lainnya. Sehingga dapat disimpulkan bahwa semakin banyak SKS yang diwajibkan bagi mahasiswa, maka mahasiswa akan semakin memahami mata kuliahnya. 
Penelitian kelima, oleh Wellman (2005) dalam jurnal berjudul "The Student Credit Hour" menemukan bahwa banyak pro dan kontra dalam penerapan sistem kredit semester di sekolah menengah, banyak pula masalah yang muncul dalam penerapannya, namun semua masalah tersebut akan dapat diatasi secara perlahan seiring berjalannya program.Kesimpulannya, sistem kredit semester merupakan sebuah pilihan yang tepat bagi kurikulum di sekolah menengah.

Pelaksanaan penelitian evaluasi ini berupaya melihat apakah program sistem kredit semester (SKS) di SMAN 1 Salatiga sudah terlaksana dengan baik atau kurang.Gambaran mengenai kerangka berfikir penelitian evaluasi program sistem kredit semester (SKS) di SMAN 1 Salatiga dapat dilihat sebagai berikut:

Gambar 3.

\section{Kerangka Berpikir Penelitian}

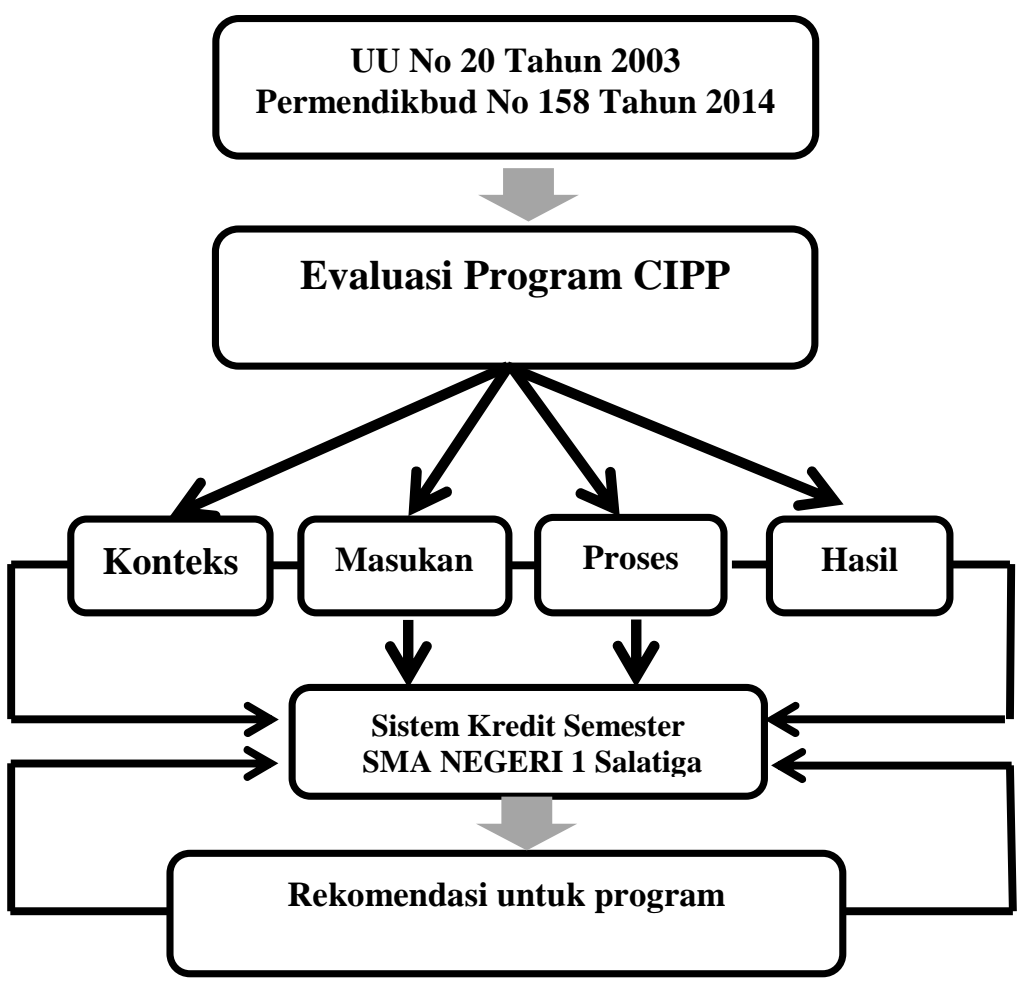

\section{METODE PENELITIAN}

Berdasarkan pada permasalahan dan tujuan penelitian, maka penelitian ini merupakan penelitian evaluatif dengan menggunakan model evaluasi CIPP (Context,Input,Process, and Product) dengan menggunakan pendekatan deskriptif kualitatif.Lokasi penelitian dilakukan di SMA Negeri 1 Salatiga yang beralamat di Jalan Kemiri I nomor 1 Salatiga. SMAN 1 Salatiga 
merupakan satu-satunya sekolah di Kota Salatiga yang telah menyelenggarakan program Sistem Kredit Semester (SKS).Guna memperoleh informasi data dalam penelitian ini, maka teknik yang dilakukan dalam pengum-pulan data penelitian melalui wawancara, observasi, dan studi dokumen.Analisis data dalam penelitian kualitatif meliputi tiga tahap yaitu: deskripsi, reduksi (terfokus) dan seleksi. Menurut Miles \& Huberman dalam Sugiyono (2013:95) "proses analisis data bersifat interaktif yaitu: data collection, data reduction, data display, conclusions: drawing/verifying”.

\section{Gambar 4.}

\section{Komponen dalam analisis data}

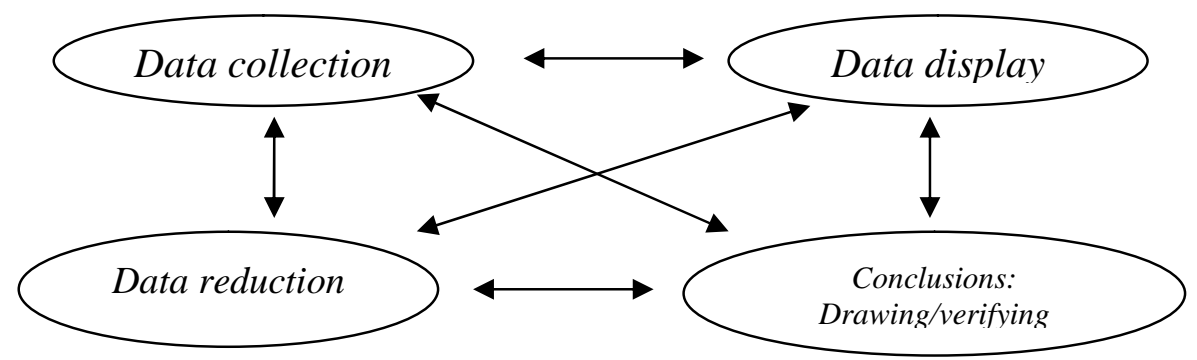

Untuk mengecek keabsahan temuan ini,peneliti memakai teknik triangulasi. Pemeriksaan yang dilakukan penulis dengan triangulasi antara lain untuk memastikan tidak ada perbedaan antara data yang diperoleh di lapangan dengan yang sesungguhnya.Untuk mencapai keabsahan data dalam penelitian ini, maka peneliti membandingkan data hasil wawancara pihak satu dengan data hasil wawancara pihak yang lain serta membandingkan hasil wawancara dengan dokumen-dokumen tentang pelaksanaan program.

\section{HASIL PENELITIAN}

\section{Aspek Konteks (Context)}

\subsection{Identifikasi Kebutuhan}

Dari kedua hasil wawancara dengan Kepala Sekolah dan Wakil Kepala Sekolah bagian Kurikulum,dapat peneliti simpulkan bahwa pada mulanya yang menjadi kebutuhan SMAN 1 Salatiga sehingga menerapkan Sistem Kredit Semester (SKS) karena adanya surat keputusan kepala dinas provinsi Jawa Tengah yang menunjuk SMAN 1 Salatiga sebagai Rintisan Sekolah Bertaraf Internasional (RSBI).Dimana dalam panduan pelaksanaannya sekolah RSBI ini diwajibkan untuk menggunakan Sistem Kredit Semester (SKS) dalam penyelenggaraan sistem program pendidikan di sekolahnya.Namun ketika RSBI dihentikan pihak sekolah tidak serta merta menghentikan program SKS,hal ini dikarenakan munculnya kebutuhan lain dalam penerapan program ini.Pihak sekolah menganggap dengan adanya program SKS sekolah 
dapat memfasilitasi peserta didik yang memiliki kategori Cerdas Istimewa (CI) untuk dapat mempersingkat masa studinya menjadi minimal 2 tahun.Setelah dilakukan evaluasi serta adanya hasil verifikasi dari Dinas Pendidikan Provinsi Jawa Tengah pada tanggak 9-14 Desember 2012 dan tanggal 4-5 September 2013, maka ketika RSBI dihentikan SMAN 1 Salatiga diberikan persetujuan untuk tetap melaksanakan SKS,dengan Surat Keputusan (SK) dari Dinas Pendidikan Pemerintah Provinsi Jawa Tengah terbit, dengan nomor 420/19148 yang bertanggal 11 Oktober 2013.

\subsection{Kebijakan dari Pemerintah}

Berdasarkan hasil studi dokumen,adapun undang-undang yang menjadi landasan bagi pelaksanaan program SKS adalah Panduan Penyelenggaraan Sistem Kredit Semester pada Sekolah Menengah Atas tanggal 13 April 2010 dari Badan Standar Nasional Pendidikan (BSNP); dan Peraturan Menteri Pendidikan dan Kebudayaan Republik Indonesia Nomor 158 tahun 2014 tentang Penyelenggaraan Sistem Kredit Semester pada Pendidikan Dasar dan Pendidikan Menengah.

\section{Aspek Masukan (Input)}

\subsection{Rencana Pelaksanaan Program}

Dari hasil wawancara dengan Kepala Sekolah,Wakil Kepala Sekolah bagian Kurikulum dan Guru di SMAN 1 Salatiga, peneliti membuat simpulan bahwa dalam perencanaan pelaksanaan program pihak sekolah telah membentuk tim khusus dalam perencanaan program yang beranggotakan Kepala Sekolah,Wakil Kepala Sekolah Bidang Kurikulum beserta Guru-guru yang masuk dalam tim bidang kurikulum yang selanjutnya disebut sebagai Tim Pengembang Kurikulum (TPK).Dalam perencanaan program Guru di SMAN 1 Salatiga tidak dilibatkan secara keseluruhan demi efisiensi waktu dan efektifitas kerja.

Dalam perencanaan program,tim pengembangan kurikulum (TPK) mengikuti beberapa diklat (pendidikan dan latihan) terkait dengan program SKS dimana pembicaranya berasal dari guru-guru SMA Negeri 78 Jakarta,dan beberapa pakar SKS dari Dinas Pendidikan Pemerintah Provinsi Jawa Tengah yang salah satunya merupakan Kepala Sekolah SMAN 1 Salatiga saat itu yakni Drs. Saptono Nugrohadi, M.Pd., M.Si. Kemudian tim pengembangan kurikulum (TPK) melakukan studi banding ke beberapa sekolah yang telah melaksanakan program SKS terlebih dahulu, yaitu SMA Negeri 3 Bandung dan SMA 78 Jakarta. Setelah melakukan diklat dan studi banding, tim pengembangan kurikulum (TPK) membuat buku 
panduan program SKS yang disesuaikan dengan kondisi dan situasi sekolah yang dikembangkan dari buku panduan yang diperoleh dari SMA Negeri 3 Bandung dan SMA 78 Jakarta.

Selanjutnya pihak sekolah mengadakan In House Training (IHT) di tahun 2013 di SMA Negeri 1 Salatiga dengan melibatkan seluruh guru dan staff sebagai peserta,dengan pembicara yang berasal dari SMA Negeri 3 Bandung. Di dalam In House Training (IHT) tersebut tim pengembangan kurikulum memberikan sosialisasi kepada guru tentang sistem kredit semester yang akan diterapkan di SMAN 1 Salatiga.

\subsection{Mekanisme Pelaksanaan Program}

Setelah berbagai sosialiasasi dilakukan dan program siap untuk dilaksanakan,pihak sekolah memberikan sosisalisasi kepada peserta didik dan orang tua peserta didik.Sosialiasi ini dilakukan di setiap tahun ajaran baru bagi para peserta didik baru dan para orang tua peserta didik baru di Masa Orientasi Peserta Didik (MOPD),sehingga peserta didik beserta orang tua mendapatkan gambaran tentang program SKS.Pihak sekolah juga memberikan buku panduan sistem kredit semester kepada peserta didik yang juga digunakan oleh para guru SMAN 1 Salatiga.Tim Kurikulum merupakan perancang dari buku panduan sistem kredit semester yang digunakan di SMAN 1 Salatiga,dimana setiap tahunnya ajaran baru buku panduan tersebut diperbaiki secara berkesinambungan terutama dari struktur beban belajar, karena dalam pelaksanaan program SKS sekolah mengalami perubahan kurikulum yang semula menggunakan Kurikulum Tingkat Satuan Pendidikan (KTSP) kemudian berganti menjadi kurikulum 2013, yang tentunya memberikan perbedaan dalam struktur beban mengajar. Setelah dilakukan sosialisasi dan peserta didik diberikan buku panduan sistem kredit semester ketika Masa Orientasi Sekolah Peserta Didik (MOPD), peserta didik kemudian diminta untuk mengisi data lintas minat yang hendak di ambil di Kartu Rencana Studi (KRS) yang sudah disiapkan oleh pihak sekolah.Sehingga ketika tahun ajaran baru berlangsung peserta didik telah mendapatkan jadwal sesuai dengan lintas minat yang dikehendaki.Sedangkan untuk kriteria pengambilan beban mengajar; penilaian, penentuan indeks prestasi, dan kelulusan; serta cara menetapkan beban belajar pihak sekolah mengikuti aturan sesuai dengan panduan dari Badan Standar Nasional Pendidikan (BSNP) tahun 2010.

\subsection{Sumber Daya Manusia}

Sumber daya manusia yang dimiliki SMAN 1 Salatiga meliputi :

\section{Guru}


Guru sebagai pelaksana program memegang peranan penting dalam ketercapaian program agar sesuai dengan tujuan awal. Apabila dilihat dari kualitas sumber daya pengajarnya, secara menyeluruh jumlah pengajar di SMAN 1 Salatiga adalah 94 guru, dengan status kepegawaian 83 Guru Tetap (pegawai negeri sipil) dan 11 guru tidak tetap (guru honorer) dengan pendidikan terakhir D2 sejumlah 1 orang, D3 sejumlah 3 orang, S1 sejumlah 83 orang dan S2/S3 sejumlah 8 orang.Berdasarkan hasil wawancara para guru yang telah peneliti lakukan di tanggal 24 Agustus 2015, 25 Agustus 2015, dan 31 Agustus 2015, peneliti menyimpulkan bahwa para guru telah mendapatkan penjelasan yang cukup jelas tentang program SKS, walaupun guru tidak dilibatkan secara langsung dalam perencanaan program.

2. Peserta didik

Dalam penerimaan peserta didik baru pihak sekolah menggunakan proses seleksi.Hal ini dikarenakan banyaknya calon peserta didik yang berminat masuk ke SMAN 1 Salatiga, namun kuota peserta didik baru yang dapat diterima oleh pihak sekolah sangat terbatas. Pada tahun pelajaran 2014/2015 peserta didik di SMA Negeri 1 Salatiga berjumlah 1215 peserta didik.

\subsection{Pembiayaan}

Berdasarkan keterangan dari Kepala Sekolah, anggaran untuk program SKS termasuk dalam kegiatan pembelajaran reguler.Anggaran yang dibutuhkan dibuat dalam Rencana Kegiatan dan Anggaran Sekolah (RKAS) yang diusulkan oleh masing-masing bidang, dimana program SKS ini masuk ke dalam bidang kurikulum.Dalam hal pembiayan pihak sekolah tidak mengalami kesulitan dengan adanya kerjasama yang baik dari Dinas Pendidikan Kota Salatiga dan orangtua peserta didik.

\subsection{Sarana dan Prasarana}

Berdasarkan hasil observasi dapat dikatakan bahwa sarana dan prasarana yang ada di SMAN 1 Salatiga tersedia dengan lengkap dan semua sarana dan prasarana yang ada digunakan secara maksimal oleh para guru dan peserta didik dalam proses belajar mengajar.Dari keterangan berbagai sumber wawancara di atas dapat disimpulkan bahwa sarana prasarana yang ada di SMAN 1 Salatiga sudah cukup baik dan sudah digunakan secara maksimal dalam kegiatan belajar mengajar,serta pengelolaan sarana dan prasarana juga sudah baik dan dapat dikatakan dari pihak bagian sarana prasarana sudah cepat tanggap dalam melakukan perbaikan-perbaikan.

\subsection{Jadwal}


Dalam pembuatan jadwal diserahkan kepada bagian kurikulum,namun tetap dalam pembuatannya bagian kurikulum membutuhkan kerjasama dari pihak guru.Dari hasil wawancara dengan pihak guru dan peserta didik dapat peneliti simpulkan jadwal yang dibuat oleh bagian kurikulum sudah sangat jelas. Sehingga peserta didik dan guru dapat melaksanakan proses belajar mengajar dengan baik.Dari hasil wawancara dan studi dokumen yang peneliti lakukan,dapat peneliti simpulkan bahwa penerapan program SKS di SMAN 1 Salatiga bersifat semi paket, hal ini dilakukan agar guru tetap dapat memenuhi kewajiban jam mengajarnya, dan juga terjadi pemerataan jam mengajar bagi semua guru, selain itu dari segi jadwal juga memudahkan bagian kurikulum dalam membagi jam mengajar para guru.Dari bagian kurikulum mengatakan dalam pembuatan jadwal sering terjadi kendala, hal ini disebabkan ada sebagian guru yang tidak bersedia mengajar mata pelajaran lain selain mata pelajaran yang diampunya sehingga guru menjadi kekurangan jam mengajar, dan dari pihak kurikulum kekurangan sumber daya manusia (guru) untuk mengajar mata pelajaran tertentu.

\section{Aspek Proses (Process)}

\subsection{Persiapan Guru}

Berdasarkan hasil wawancara yang dilakukan kepada salah satu guru di SMAN 1 Salatiga diperoleh data bahwa dalam mempersiapkan pembelajaran dengan program SKS dilakukan dengan membuat rencana pembelajaran yaitu RPP (rencana Pelaksanaan Pembelajaran), silabus, program tahunan (Prota) dan program semester (Promes) yang dibuat di setiap awal tahun ajaran baru melalui rapat kerja (Raker) dimana masing-masing musyawarah guru mata pelajaran (MGMP) bekerja bersama timnya untuk membuat persiapan pembelajaran.Sedangkan dalam pelaksanaan pembelajaran maisng-masing guru menggunakan metode pembelajaran yang beragam sesuai dengan kebutuhan peserta didik di kelas.

\subsection{Pelaksanaan Sistem Kredit Semester}

Pelaksanaan SKS di SMAN 1 Salatiga sudah berjalan sesuai dengan tujuan awal.Dimana peserta didik yang aktif akan mendapatkan SKS yang lebih banyak sesuai dengan Indeks Prestasi Kumulatif (IPK) yang didapatkan dimana mereka dapat mengambil pengayaan di semester selanjutnya Pelaksanaan pembelajaran dengan program SKS di SMAN 1 Salatiga masih semi paket.Dimana masih terdapat mata pelajaran yang diwajibkan di masing-masing jurusan (IPA, IPS, dan Bahasa), sedangkan untuk mata pelajaran peminatan dan lintas minat,peserta didik diberikan kebebasan untuk memilih mata pelajarannya sendiri. 
Sedangkan bagi peserta didik yang ingin mengambil Percepatan, pihak sekolah membuat berbagai seri mata pelajaran dimana dalam pelaksanaannya peserta didik dibimbing agar dapat menyelesaikan seluruh SKSnya dalam jangka waktu 2 tahun, agar peserta didik tersebut dapat mengikuti Ujian Nasional bersama dengan peserta didik lainnya. Hal inilah yang menjadi salah satu kendala penerapan program SKS, pihak pemerintah belum memfasilitasi peserta didik yang dapat menyelesaikan masa studinya ketika berada di semester antara.

\subsection{Penilaian Hasil Pembelajaran}

Pelaksanaan penilaian hasil belajar di SMAN 1 Salatiga dilakukan sesuai dengan panduan dari BSNP, dimana penilaian meliputi penilaian kompetensi sikap, penilaian kompetensi pengetahuan, dan penilaian kompetensi keterampilan.Pelaksanaan penilaian hasil belajar di SMAN 1 Salatiga mengalami perbaikan-perbaikan sesuai dengan kebutuhan sekolah, dimana dalam penilaian kompetensi pengetahuan terutama dalam tes tertulis, bagian kurikulum membuat tes ulangan harian yang dilakukan secara serempak.Pelaksanaan penilaian program SKS ini dijabarkan ke dalam laporan hasil belajar peserta didik,dimana dari bagian kurikulum telah membuat desain untuk laporan hasil belajarnya.Desain ini kemudian dijadikan sebuah program komputer, dimana hal ini memudahkan guru dalam memasukkan nilai.

\section{Aspek Produk}

\subsection{Ketercapaian Tujuan}

Dari hasil wawancara dengan berbagai pihak diperoleh kesimpulan program sistem kredit semester (SKS) sudah berjalan sesuai dengan tujuan awal program. Dimana dalam aspek komponen konteks disebutkan tujuan program SKS adalah memfasilitasi peserta didik yang memiliki kategori cerdas istimewa (CI) untuk dapat menyelesaikan masa studinya menjadi 2 tahun, dan dalam pelaksanaannya SMA Negeri 1 Salatiga telah membuka kelas percepatan yang telah berjalan dari tahun pelajaran 2014/2015 sampai sekarang dengan jumlah peserta didik kelas percepatan untuk kelas X sebanyak 30 orang, dan kelas XI sebanyak 21 anak. Selain kelas percepatan tersebut peserta didik juga tetap memiliki kesempatan untuk mmpersingkat masa studinya melalui kelas reguler namun dengan tingkat SKS yang lebih banyak dibandingkan teman-teman satu angkatannya.

\subsection{Keberlanjutan Program}

Berdasarkan hasil wawancara dengan Wakil Kepala Sekolah bagian kurikulum, program SKS yang diterapkan di SMA Negeri 1 Salatiga sudah cukup layak dijadikan role 
model bagi sekolah-sekolah lain.Walaupun dalam penerapannya di SMA Negeri 1 Salatiga masih mengalami beberapa kendala, namun kendala-kendala tersebut dapat teratasi seiring berjalannya program.Pihak penyelenggara program juga tetap akan terus melakukan perbaikan agar program SKS yang dijalankan semakin baik untuk kedepannya, dan semakin meminimalisir kendala-kendala yang dihadapi.

\section{PEMBAHASAN}

Dari hasil penelitian yang peneliti telah lakukan di SMA Negeri 1 Salatiga mengenai sistem kredit semester, dari segi konteks pihak sekolah melaksanakan program tersebut berdasarkan atas kebutuhan:

a) Sebagai sekolah unggulan sekaligus mantan sekolah yang menerapkan RSBI maka SMAN 1 Salatiga berupaya untuk menjadi sekolah rujukan,salah satunya untuk mengakomodasikan kebutuhan anak-anak dengan kategori Cerdas Istimewa (CI). Sehingga pihak sekolah ingin memfasilitasi peserta didik dengan kategori Cerdas Istimewa tersebut dengan melaksanakan program SKS.

b) Dari segi konteks regulasinya, adanya peluang yang dimiliki SMAN 1 Salatiga sebagai sekolah yang ditunjuk oleh pihak Dinas Pendidikan untuk melaksanakan program SKS, hal ini juga didukung dengan dikeluarkannya SK Penyelenggaraan Program SKS dan SK Penyelenggaraan Program Percepatan Belajar dengan Pengayaan.Program SKS mulai dilaksanakan di SMA Negeri 1 Salatiga sejak tahun ajaran 2012/2013 dan telah menjadi program unggulan di SMA Negeri 1 Salatiga sampai saat ini.

Dari segi masukan (Input) Dalam penelitian di SMA Negeri 1 Salatiga,sumber-sumber yang dimiliki untuk mencapai tujuan program SKS meliputi rencana pelaksanaan, mekanisme pelaksanaan, guru, peserta didik, pembiayaan, sarana dan prasarana, serta jadwal.Berdasarkan hasil penelitian yang telah peneliti lakukan sesuai dengan hasil penelitian Nurmalisa (2013) bahwa terdapat pengaruh kuat antara kesiapan sekolah terhadap pelaksanaan sistem kredit semester. SMA Negeri 1 Salatiga sebagai salah satu SMA favorit di Salatiga memiliki sumber daya manusia yang sangat kompeten dari segi guru, dan memiliki peserta didik dengan prestasi nilai unggulan dibandingkan SMA Negeri lainnya, dikarenakan adanya seleksi yang ketat dalam penerimaan peserta didik baru. Oleh karena itu kesiapan sekolah tersebut juga merupakan faktor penting dalam keterlaksanaan program SKS. 
Hasil penelitian ini juga relevan dengan hasil penelitian Sa'diyah (2012) dimana sebagai pelaksana pemahaman guru di SMA Negeri 1 Salatiga sudah cukup mendalam. Guru tidak hanya mengetahui garis besar program SKS, tetapi juga memahami konsep dasar program SKS dan ikut terlibat secara langsung dalam pelaksanaan serta implementasinya di sekolah.

Dari segi proses,hasil penelitian ini juga sesuai dengan penelitian Rakhmawati (2011) dimana implementasi program SKS di SMA Negeri 1 Salatiga sudah cukup sesuai dengan panduan penyelenggaraan program yang diterbitkan oleh BSNP, walaupun terdapat beberapa improvisasi dari sekolah berkaitan dengan teknis pelaksanaan di lapangan karena menyesuaikan dengan situasi dan kondisi sekolah di SMA Negeri 1 Salatiga.

Dari segi hasil (product), hasil penelitian ini juga sesuai dengan hasil penelitian Feldhaus dan Omari (2010), dimana peserta didik yang mengambil SKS lebih banyak memiliki kecerdasan akademik yang melebihi rata-rata teman-temanya, dan dari segi nilaipun mereka lebih unggul dibandingkan teman-temannya, sehingga para peserta didik di SMAN 1 Salatiga dengan kategori Cerdas Istimewa mampu menyelesaikan pendidikannya di jenjang sekolah menengah denagn jangka waktu 2 tahun.

Hasil penelitian ini juga sesuai dengan penelitian Wellman (2005) yang menyebutkan banyak sekali pro dan kontra dalam penerapan sistem kredit semester di sekolah menengah, banyak pula masalah yang akan muncul dalam penerapannya.Namun permasalahanpermasalah tersebut dapat teratasi dengan baik, seperti yang terjadi di SMA Negeri 1 Salatiga.

\section{SIMPULAN DAN SARAN}

\section{Simpulan}

Berdasarkan hasil penelitian dan pembahasan mengenai "Evaluasi Program Sistem Kredit Semester di SMA Negeri 1 Salatiga”, maka ditarik beberapa simpulan sebagai berikut:

1. Penyelenggaraan program sistem kredit semester di SMA Negeri 1 Salatiga dari segi konteks, berdasarkan atas kebutuhan yang ada pada sekolah yaitu untuk memfasilitasi peserta didik dengan kategori cerdas istimewa (CI) agar dapat memaksimalkan potensi yang dimilikinya.

2. Penyelenggaran program sistem kredit semester di SMA Negeri 1 Salatiga dari segi masukan (input), meliputi rencana pelaksanaan, mekanisme pelaksanaan, guru, peserta didik, pembiayaan, sarana prasarana dan jadwal cukup memadai.

3. Penyelenggaraan program sistem kredit semester di SMA Negeri 1 Salatiga dari segi proses telah dilaksanakan sesuai perencanaan program, walaupun program SKS yang 
berjalan masih semi paket karena kepentingan pemenuhan jam mengajar guru, dan keterbatasan ruang.

4. Penyelenggaraan program sistem kredit semester di SMA Negeri 1 Salatiga dari segi hasil hasil sudah sesuai dengan tujuan awal program, sehingga saat ini sudah terdapat 2 kelas percepatan di SMA Negeri 1 Salatiga. Selain itu terdapat peningkatan hasil ujian nasional dari tahun ke tahun.

5. Pelaksanana program SKS di SMA Negeri 1 Salatiga berdasarkan kriteria rekomendasi kebijakan meliputi efektivitas; efisiensi; kecukupan; perataan, responsivitas dan kelayakan; program SKS yang dilaksanakan di SMAN 1 Salatiga telah memenuhi keenam kriteria tersebut, sehingga pelaksanaan program tetap dapat dilanjutkan namun dengan beberapa revisi program yang berkaitan dengan masukan (Input) bagi program.

\section{Saran}

Berdasarkan evaluasi dari masing-masing aspek dalam CIPP ada beberapa saran untuk pihak sekolah sebagai berikut:

a. Sekolah perlu mengusulkan anggaran dana kepada Dinas Pendidikan agar sarana prasarana yang dimiliki oleh SMA Negeri 1 Salatiga dapat menjadi lebih baik lagi. Sarana dan prasarana yang perlu diperbaiki berupa gedung perpustakaan yang lebih luas dengan koleksi buku yang lebih banyak, agar dapat menampung peserta didik. Selain itu diperlukan juga ruang kelas yang lebih banyak agar program SKS dapat berjalan kebih baik lagi dan bukan semi paket.

b. Bagi bagian kurikulum, diharapkan dalam membuat jadwal ulangan harian, UTS, UAS, maupun UKK juga memperhatikan kebutuhan peserta didik, agar peserta didik dapat lebih maksimal dalam mengerjakan tes. Contohnya ulangan tengah semester mata pelajaran matematika dapat disandingkan dengan mata pelajaran yang bersifat hafalan.

c. Kepada guru, diharapkan guru mampu menguasai semua bidang pelajaran, dan dapat mentolerir ketika ditempatkan pada mata pelajaran tertentu yang tidak sesuai dengan bidangnya. Dari pihak kurikulum bertujuan baik agar para guru dapat memenuhi jam mengajar, sehingga perlu adanya kerjasama yang baik dari pihak guru agar program dapat berjalan dengan lancar.

d. Sekolah disarankan untuk tetap menggunakan program SKS, karena berdasarkan hasil penelitian pelaksanaan program SKS di SMAN 1 Salatiga telah berjalan dengan baik dan lancar, serta telah memenuhi 6 kriteria rekomendasi kebijakan untuk dilanutkan, 
walaupun masih terdapat beberapa kekurangan dari segi masukan (Input) tetapi hal tersebut tidak menjadi kendala yang besar bagi pelaksanaan program SKS. 


\section{DAFTAR PUSTAKA}

Arikunto, S dan Abdul Jabar, C.S. 2010.Evaluasi Program Pendidikan. Jakarta: Bumi Aksara. Aunurrahman. 2009. Belajar dan Pembelajaran. Bandung: Alfabeta.

Bloom, Benjamin S. 1976. Human Characteristic and School Learning. New York: Mc Graw Hill book Company.

BSNP. 2010. Panduan Penyelenggaraan Sistem Kredit Semester untuk Sekolah Menengah Pertama Madrasah Tsanawiyah dan Sekolah Menengah Atas/Madrasah Aliyah. Jakarta:BSNP.

Hawadi, Reni A. 2001. Kurikulum berdiferensiasi Panduan Bagi Penyelenggaraan Program Percepatan Belajar. Jakarta: PT.Grasindo.

Hirsch, E.D. 1999. The Schools We Need and Why We Don't Have It. New York: Anchor Books Double Day.

Jaedun, Amat. 2010. Metode Penelitian Evaluasi Program. Makalah disampaikan pada kegiatan Pelatihan Metode Penelitian Evaluasi Kebijakan dan Evaluasi Program Pendidikan di Lembaga Penelitian. Universitas Negeri Yogyakarta 23-24 Agustus 2010.

Mulyatiningsih. 2011. Riset Terapan Bidang Pendidikan dan Tehnik. Yogyakarta: UNY Press.

Nugroho, Riant. 2008. Public Policy, Teori Kebijakan - Analisis Kebijakan - Proses Kebijakan Perumusan, Implementasi, Evaluasi, Revisi Risk Management dalam Kebijakan Publik, Kebijakan sebagai The Fifth Estaste - Metode Penelitian Kebijakan. Jakarta: PT. Elex Media Komputindo.

Nurmalisa, dkk. 2013. Pengaruh Kesiapan Sekolah Terhadap Pelaksanaan Program Sistem Kredit Semester di SMA Negeri 9 Bandar Lampung Tahun Pelajaran 2012/2013. Jurnal Kultur Demokrasi, Volume 1 Nomor 2, halaman 1.

Rakhmawati, Anisya Febriana. 2011. Implementasi Program Sistem Kredit Semester (SKS) dalam Upaya Peningkatan Mutu Pendidikan di Sekolah Menengah Atas Negeri 3 Bandung. Skripsi. Bandung: Universitas Pendidikan Indonesia.

Sa'diyah, Halimatus. 2012. Implementasi Kurikulum Tingkat Satuan Pendidikan pada Mata Pelajaran Sejarah dengan Sistem Kredit Semester di SMA Negeri 2 Malang Tahun Ajaran 2011/2012. Artikel Jurnal Universitas Muhammadiyah Malang.

Stufflebeam, L. Daniel, Shinkfield J. Anthony. 2007. Education, Theory, Models and Applications. San Francisco: Jossey Bass. 
Evaluasi Program Sistem Kredit Semester Di Sma Negeri 1 Salatiga

Sugiyono, 2013. Metode Penelitian Kombinasi. Bandung: CV. Alfabeta.

Wirawan. 2012. Evaluasi: Teori, Model, Standar, Aplikasi dan Profesi. Jakarta: Rajawali Pres. 